\title{
ANALYSIS OF ECONOMIC AFFORDABILITY OF THE ANTIHYPERTENSIVE THERAPY FOR THE TREATMENT OF HYPERTENSION
}

\author{
L.V.Iakovlieva, O.S.Tsvyk
}

National University of Pharmacy

Key words: hypertension; affordability ratio; coefficient of the solvency adequacy; first line antihypertensive drugs

\begin{abstract}
Hypertension (HTN) is a common disease, which main manifestation is high blood pressure (BP). Nowadays, HTN is found in 30-40\% of the adult population of the world. The prevalence of HTN in the population increases with age. Among people aged 18-29 years old the prevalence of HTN is 4\%; aged 50-59 years old - 44\%; among people aged 60-69 years old $-54 \%$, and aged 70 and older $-65 \%$. The aim of this study was to evaluate the range and economic affordability of antihypertensive drugs. The analysis has shown that the range of the first line antihypertensive drugs includes 35 INNs of drugs represented by 570 TNs. Most part of the market - 68.5\% is taken by foreign drugs and only 31.1\% - by domestic drugs. The range of antihypertensive drugs includes drugs of different generations: in addition to well-known drugs there are also new ones that have significant advantages both in terms of clinical efficiency and safety. The analysis of economic affordability has shown that the vast majority of drugs are highly affordable for the Ukrainian consumers, and their total number when calculated at the maximum price is 54.3\% (19 INNs) of all drugs presented at the Ukrainian pharmaceutical market. The share of drugs with average affordability is 37.1\% (13 INNs); it allows the average citizen of Ukraine taking drugs during the entire treatment of HTN without experiencing a significant impact on his/her own budget, and only $8.6 \%$ (3 INNs) are drugs with low affordability. But drugs with low affordability are modern and have significant advantages when used in clinical practice compared to available analogs.
\end{abstract}

$\mathrm{H}$ ypertension (HTN) is a common disease, which main manifestation is high blood pressure (BP) often combined with regional vascular tone disorders in the absence of causal relationship with the primary organic damage of any organs or systems. HTN is characterized by staging in development of symptoms. In more than $90 \%$ of cases BP can be idiopathic (primary, essential), and in this case it is called HTN. In 5-10\% of cases, HTN has an established cause (secondary HTN) [1, 2].

Increase in systolic BP over $140 \mathrm{~mm} \mathrm{Hg}$ or diastolic over $90 \mathrm{~mm} \mathrm{Hg}$ should be understood as HTN. There are the following HTN stages: I - no objective manifestations of organic changes in vital organs; II - the presence of objective manifestations of organic changes in vital organs (left ventricular hypertrophy, generalized or focal narrowing of the retinal artery, proteinuria or hypercreatinemia, which are not initially associated with kidney diseases);
III - HTN complications appear (myocardial infarction, chronic heart failure, ischemic and hemorrhagic stroke, renal failure $[3,4,5]$.

According to statistics, $12,157,099$ of hypertensive patients, i.e. $26.4 \%$ of the adult population, were recorded in Ukraine in 2013. The prevalence of the disease is $26,793.9$ per 100 thousand of the population, including new cases - 8,978.8 persons. There has been a steady increase in the prevalence of HTN - more than doubled as compared to 1998 and by $170 \%$ - compared to 2000 . The prevalence of HTN among circulatory diseases (CD) in adults is $46.8 \%$, i.e. almost half of patients with CD have high BP $[7,9]$.

In Ukraine, according to epidemiological studies, the age-adjusted prevalence rate of HTN in the urban population is $29.6 \%$ for both men and women. In the rural population the prevalence of HTN is higher $-36.3 \%$, including $37.9 \%$ - among men, and $35.1 \%$ - in women.
Based on data of the Ministry of Health, when analyzing the HTN structure by the level of BP, $50 \%$ of patients had arterial hypertension (AHT) of the $1^{\text {st }}$ level, every third - AHT of the $2^{\text {nd }}$ level, and every fifth - AHT of the $3^{\text {rd }}$ level [7].

Among those with high blood pressure $67.8 \%$ of rural and $80.8 \%$ of urban residents are aware of the presence of the disease, $38.3 \%$ and $48.4 \%$ are treated, and the treatment efficiency is $8.1 \%$ and $18.7 \%$, respectively. Thus, the situation as to the AHT monitoring is unsatisfactory in both rural and urban population, but it is extremely unfavorable in rural areas [6].

Based on the data from a largescale meta-analysis it has been confirmed that the first line drugs for treating HTN are diuretics (thiazide and thiazide-like) (the main mechanism of action of thiazide diuretics is the rapid elimination of sodium and potassium ions, thus achieving maximum excretion of liquid from the body that leads to decrease of BP), angiotensinconverting-enzyme inhibitors 


\section{Groups of antihypertensive drugs, their International Nonproprietary Names (INNs) and the number of trade names (TNs) presented at the Ukrainian pharmaceutical market}

\begin{tabular}{|l|l|}
\hline \multicolumn{1}{|c|}{ Group of antihypertensive drugs } & \multicolumn{1}{c|}{ INNs and the number of TNs } \\
\hline $\begin{array}{l}\text { Beta-blockers (C07A) } \\
\text { 8 INNs, 143 TNs }\end{array}$ & $\begin{array}{l}\text { Propranolol (4 TNs), metoprolol (23 TNs H), atenolol (12 TNs), } \\
\text { betaxolol (3 TNs), bisoprolol (59 TNs), esmolol (1 TN), nebivolol } \\
\text { (10 TNs), carvedilol (31 TNs) }\end{array}$ \\
\hline $\begin{array}{l}\text { Angiotensin-converting-enzyme inhibitors } \\
\text { (ACE inhibitors) (C09A) } \\
\text { 10 INNs, 172 TNs }\end{array}$ & $\begin{array}{l}\text { Captopril (8 TNs), enalapril (41 TNs), lisinopril (60 TNs), perindopril } \\
\text { (10 TNs), ramipril (40 TNs), fosinopril (4 TNs), spirapril (1 TN), } \\
\text { moexipril (4 TNs), zofenopril (3 TNs), enalaprilat (1 TN) }\end{array}$ \\
\hline $\begin{array}{l}\text { Angiotensin II receptor blockers (AA II) (C09D) } \\
\text { 6 INNs, 94 TNs }\end{array}$ & $\begin{array}{l}\text { Losartan (34 TNs), eprosartan (1 TN), valsartan (21 TNs), ibesartan } \\
\text { (7 TNs), candesartan (13 TNs), telmisartan (18 TNs) }\end{array}$ \\
\hline $\begin{array}{l}\text { Calcium channel blockers (CCB) (C08C) } \\
\text { 9 INNs, 143 TNs }\end{array}$ & $\begin{array}{l}\text { Amlodipine (66 TNs), felodipine (4 TNs), nifedipine (23 TNs), } \\
\text { nimodipine (5 TNs), nitrendipine (2 TNs), lercanidipine (10 TNs), } \\
\text { lacidipine (2 TNs), verapamil (22 TNs), diltiazem (9TNs) }\end{array}$ \\
\hline $\begin{array}{l}\text { Thiazide and thiazide-like diuretics (TD) (C03B) } \\
\text { 2 INNs, 18 TNs }\end{array}$ & Hydrochlorothiazide (3 TNs), indapamide (15 TNs) \\
\hline
\end{tabular}

(ACE inhibitors) (the mechanism of action of ACE inhibitors is inhibition of angiotensin-converting enzyme, which catalyzes formation of angiotensin II and at the same time stimulates degradation of bradykinin to inactive fragments). The consequence of reducing the concentration of angiotensin II in the circulatory bed and tissues is inhibition of a number of its effects, including BP lowering. Calcium channel blockers are also the first line drugs; calcium antagonists block the entry of calcium ions into vascular and myocardial cells, reduce the conversion of energy associated with phosphates into mechanical work, thus decreasing the ability of the myocardium to develop the strain, and reduce its contractility. The effect of these drugs on the wall of coronary vessels leads to their expansion (the antispasmodic effect) and increase in the coronary blood flow, and impact on peripheral arteries - to systemic arteriolar dilation, reduction of peripheral resistance, lowering of systolic and diastolic BP (the hypotensive action). Other drugs for treating HTN are angiotensin II receptor blockers (the mechanism of action is to block binding of angiotensin II to receptors, and it leads to vasodilation, reduction of aldosterone release, and sodium reabsorption in the kidneys; these mechanisms provide the antihypertensive effect) and $\beta 1$-blockers (the mechanism of action is blocking betaadrenergic receptors of the heart, resulting in decreased heart rate (HR) and decreased myocardial contractility. This leads to decrease in cardiac output, decreased myocardial contractility, inhibition of central adrenergic effects (for substances penetrating through BBB), and the antirenin effect of drugs causes decrease in systolic and then diastolic pressure) [7].

The above groups of drugs are considered to be suitable for both the initial and supporting antihypertensive therapy [7].

The availability of a large number of pharmacological drugs for antihypertensive therapy greatly increases the chance of achieving blood pressure control in vast majority of patients. It is important to take into account the proven fact that the BP decrease only by 5-6 $\mathrm{mm} \mathrm{Hg}$ is associated with reduced mortality due to cardiovascular diseases by $21 \%$, frequency of strokes - by $42 \%$ and myocardial infarction - by $14 \%[6,7]$.

The data of evidence-based medicine suggest that the rational antihypertensive therapy significantly improves the prognosis of patients with HTN. Therefore, the aim of this study was to evaluate the cost and economic affordability of antihypertensive drugs.
To achieve this goal, it was necessary to solve the following problems:

1. to conduct the analysis of the range of antihypertensive drugs presented at the Ukrainian pharmaceutical market;

2 . to assess the economic affordability of the first line antihypertensive drugs for patients.

\section{Materials and Methods}

The analysis of the range of domestic and foreign antihypertensive drugs at the pharmaceutical market was conducted based on the data of Morion Pharmstandard Analytical Market Research System [8]. To assess the economic affordability of the antihypertensive therapy the coefficient of the solvency adequacy (Ca.s) showing what percentage of the average wage of the Ukrainian consumer should be spent on the course of treatment with the drug was used. The greater the value of Ca.s is, the less affordable is the drug for the consumer. The coefficient of the solvency adequacy was calculated by the formula:

$$
\text { Ca.s }=\text { P.c.t. } / \text { Wa.w. } \times 100 \% \text {, }
$$

where: Ca.s - is the coefficient of the solvency adequacy; P.c.t. - is the cost of treatment; Wa.w. - is the average wage within the year under study [10].

The value of the average wage was found on the website: 
Domestic drugs, $31.5 \%$

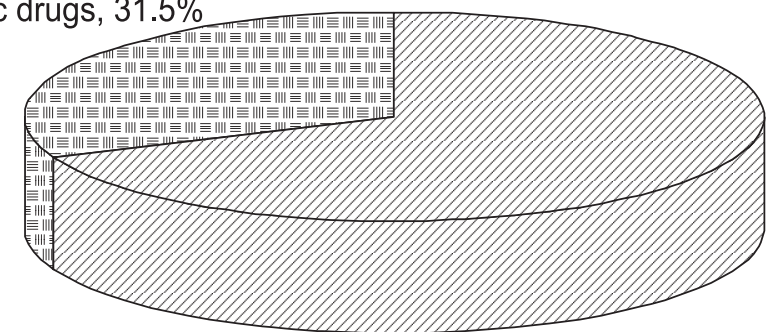

Foreign drugs, $68.5 \%$

Fig. 1. The ratio of foreign and domestic drugs among the first line antihypertensive drugs

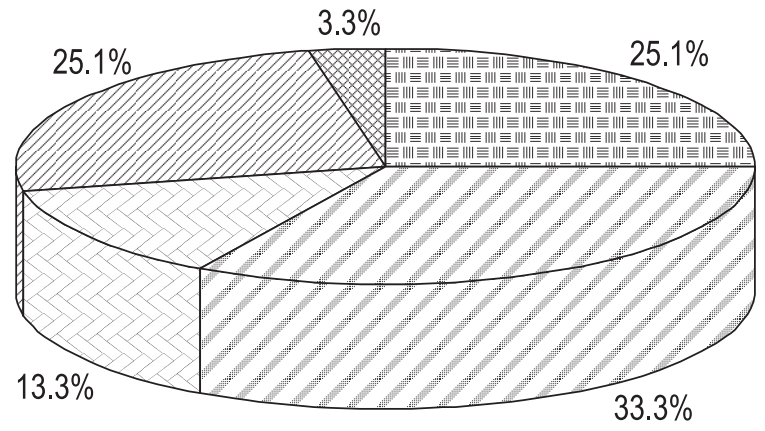

Beta-blockers - $25.1 \%$

ACE inhibitors - 33.4\%

Angiotensin II receptor blockers - $13.3 \%$

Calcium channel blockers $-25.1 \%$

Thiazide diuretics $-3.3 \%$

Fig. 2. The proportion of TNs of the first line antihypertensive drugs of different pharmacological groups at the Ukrainian pharmaceutical market

www.ukrstat.gov.ua. The course of treatment for calculations was 30 days.

\section{Results and Discussion}

There were 5 groups of first line antihypertensive drugs at the Ukrainian pharmaceutical market (Tab. 1).

The range of antihypertensive drugs has 35 International Nonproprietary Names (INNs) of drugs presented by 570 trade names (TNs). The share of foreign drugs is $68.5 \%$, and domestic drugs $31.5 \%$ (Fig. 1).

The greatest number of TNs of drugs $33.3 \%$ is presented in the group of angiotensin-converting-enzyme inhibitors (190 TNs), which leaders are enalapril (41 TNs), lisinopril (60 TNs) and ramipril (40 TNs), the significant share belongs to beta-blockers - $25.1 \%$ (143 TNs) and calcium channel blockers (143 TNs) - 25.1\%, a slightly lower proportion is taken by angiotensin II receptor blockers $13.3 \%$, and the lowest share of
$3.3 \%$ is taken by the group of thiazide diuretics (18 TNs) (Fig. 2).

The next stage of this study was to assess economic affordability of antihypertensive drugs belonging to the standard of medical care of patients with HTN and those present at the Ukrainian pharmaceutical market (Tab. 2).

Based on the data obtained it has been found that all antihypertensive drugs are highly affordable (Ca.s $<5 \%$ ), except for Felodip and Enap $^{\circledR}$, by the Ca.s value at the minimum price per the course of treatment (30 days). The coefficient of the solvency adequacy of the most drugs provides availability of the drug and guarantees the sale against the low paying capacity of the population. Felodip belongs to blockers of "slow" calcium channels of dihydropyridines. It reduces the size of myocardial infarction and protects against reperfusion complications. It practically has no negative effects with the minimal effect on the cardiac conduction system. Enap ${ }^{\circledR}$ inhi- bits angiotensin-converting enzyme, reduces the concentration of angiotensin II and aldosterone in the blood and improves the kallikrein-kinin vasodepressor system functioning. The drug reduces TPR, SBP and DBP. The action begins in 1.5-15 min after intravenous injection, reaches the maximum in 1-4 hours and lasts about 6 hours. These drugs have average affordability, their Ca.s $=5.02 \%$ and $7.88 \%$, respectively. These drugs are less affordable, but taking into account the peculiarities of their pharmacological profile they can be used widely in Ukraine.

The Ca.s values calculated by the maximum price show that drugs by 13 INNs are with average affordability (Ca.s < 15\%) and by 3 INNs - with low affordability (Ca.s > 15\%). The drugs with low affordability include: Diovan (valsartan) (film-coated tablets, $80 \mathrm{mg}$, No.28 Novartis Pharma (Switzerland); it has a selective antagonistic action with respect to the receptor apparatus of angiotensin II (AT II). Diovan has no active metabolite and does not require biotransformation during the initial passage through the liver. It has high (95\%) ability to bind to plasma proteins, primarily albumin. The effect of the dose lasts for up to 24 hours, it increases compliance of patients to therapy. The efficiency does not depend on sex, age and race. Valsartan is not inferior to amlodipine, hydrochlorothiazide and lisinopril by its antihypertensive efficiency and even exceeds the latter by tolerability. The probability of cough when using valsartan is very low due to the lack of impact on ACE, which is responsible for degradation of bradykinin. Comparison of Diovan with ACE inhibitor showed that the incidence of dry cough was significantly lower in patients receiving Diovan than in patients treated with ACE inhibitor (2.6 vs. $7.9 \%$, respectively). The use of this drug is not accompanied by a sharp decrease in blood pressure, or other adverse clinical consequences. 
Indicators of economic affordability of the first line antihypertensive drugs for $\mathbf{2 0 1 4}$

\begin{tabular}{|c|c|c|c|c|}
\hline INN & $\begin{array}{c}\text { min cost of } \\
\text { a package }(U A H)\end{array}$ & $\begin{array}{c}\text { Ca.s min per the } \\
\text { course of treatment } \\
\text { (30 days) }\end{array}$ & $\begin{array}{c}\text { max cost of } \\
\text { a package }(U A H)\end{array}$ & $\begin{array}{c}\text { Ca.s max per the } \\
\text { course of treatment } \\
\text { (30 days) }\end{array}$ \\
\hline \multicolumn{5}{|c|}{ Beta-blockers (C07A) } \\
\hline Propranolol & 42.59 & 1.35 & 76.11 & 2.42 \\
\hline Metoprolol & 8.71 & 0.28 & 197.38 & 6.27 \\
\hline Atenolol & 6.04 & 0.19 & 59.16 & 1.88 \\
\hline Betaxolol & 76.33 & 2.42 & 183.85 & 4.19 \\
\hline Bisoprolol & 9.61 & 0.31 & 104.4 & 3.3 \\
\hline Esmolol & $2,591.32$ & - & $2,591.32$ & 82.27 \\
\hline Nebivolol & 47.28 & 1.5 & 126.92 & 4.03 \\
\hline Carvedilol & 24.19 & 0.77 & 453.29 & 14.39 \\
\hline \multicolumn{5}{|c|}{ Angiotensin-converting-enzyme inhibitors (C09A) } \\
\hline Captopril & 21.56 & 0.68 & 124.15 & 3.94 \\
\hline Enalapril & 5.53 & 0.18 & 156.12 & 4.96 \\
\hline Lisinopril & 6.41 & 0.2 & 498.03 & 15.81 \\
\hline Perindopril & 39.66 & 1.26 & 102.75 & 3.26 \\
\hline Ramipril & 27.38 & 0.87 & 190.75 & 6.06 \\
\hline Fosinopril & 82.07 & 2.61 & 196.28 & 6.23 \\
\hline Spirapril & 115.07 & - & 115.07 & 3.65 \\
\hline Moexipril & 77.03 & 2.45 & 230.13 & 7.31 \\
\hline Zofenopril & 137.4 & 4.36 & 178.29 & 4.66 \\
\hline Enalaprilat & 248.2 & - & 248.2 & 7.88 \\
\hline \multicolumn{5}{|c|}{ Angiotensin II receptor blockers (C09D) } \\
\hline Losartan & 16.11 & 0.51 & 261.65 & 8.31 \\
\hline Eprosartan & 122.97 & - & 122.97 & 3.9 \\
\hline Valsartan & 58.71 & 1.86 & $1,126.49$ & 35.76 \\
\hline Ibesartan & 57.14 & 1.81 & 151.39 & 4.81 \\
\hline Candesartan & 26.37 & 0.84 & 254.59 & 8.08 \\
\hline Telmisartan & 39.23 & 1.25 & 196.31 & 6.23 \\
\hline \multicolumn{5}{|c|}{ Calcium channel blockers (C08C) } \\
\hline Amlodipine & 8.96 & 0.28 & 206.12 & 6.54 \\
\hline Felodipine & 158.24 & 5.02 & 309.57 & 9.83 \\
\hline Nifedipine & 3.97 & 0.13 & 461.81 & 14.66 \\
\hline Nimodipine & 71.22 & 2.26 & 88.14 & 2.80 \\
\hline Nitrendipine & 112.43 & 3.57 & 153.95 & 4.89 \\
\hline Lacidipine & 130.58 & 4.15 & 140.13 & 4.45 \\
\hline Lercanidipine & 37.85 & 1.20 & 95.30 & 3.03 \\
\hline Verapamil & 3.95 & 0.13 & 351.92 & 11.17 \\
\hline Diltiazem & 32.39 & 1.03 & 139.61 & 4.43 \\
\hline \multicolumn{5}{|c|}{ Thiazide and thiazide-like diuretics (C03B) } \\
\hline Hydrochlorothiazide & 27.52 & 0.87 & 115.5 & 3.67 \\
\hline Indapamide & 16.26 & 0.52 & 91.42 & 2.9 \\
\hline
\end{tabular}

Another drug with low affordability presented at our market is Lizinovel (tabl., $10 \mathrm{mg}$, in blister, No.10, Astrapharm (Ukraine) ACE inhibitor. Inhibition of the ACE activity leads to reduction of an- giotensin II in the blood plasma, decrease in aldosterone release and, as a consequence, lowering of blood pressure in patients with hypertension, and improves the course of heart failure. In pati- ents with essential hypertension decrease of blood pressure is associated with decrease in total peripheral resistance with little change in the heart rate. The hypotensive effect develops in almost an 


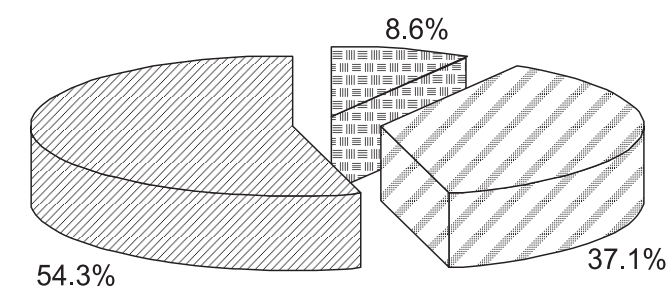

Drugs with low affordability ( 3 INNs) $-8.6 \%$

Drugs with average affordability (13 INNs) $-37.1 \%$

Highly affordable drugs (19 INNs) $-54.3 \%$

Fig. 3. The ratio of affordability of antihypertensive drugs for the Ukrainian consumers by the value of Ca.s calculated on the basis of maximum prices for drugs

hour after administration and reaches its maximum about 6 hours later. The effect lasts for 24 hours and depends on the dose that increases compliance of the patient. The third drug included in the group of drugs with low affordability is Brevibloc (solution for injections, $10 \mathrm{mg} / \mathrm{ml}, 10 \mathrm{ml}$ vial, No.5, Baxter AG (Switzerland) - it blocks $\beta 1$-adrenergic receptors, but unlike other drugs of this group Brevibloc differs in ultrashort duration of action (the absolute therapeutic effect develops within 2 min and terminates in 15-20 min after completing the infusion. $\mathrm{T}_{1 / 2}-9 \mathrm{~min}$ ), it provides the successful use in acute situations in case of hypertensive crisis, severe arrhythmias and heart surgery. This drug is almost un- affordable for the Ukrainian consumers as Ca.s for it is $82.27 \%$.

According to the data calculated at the maximum price for the drug and the Ca.s value per the course of treatment of 30 days it has been found that $54.3 \%$ (19 INNs) of antihypertensive drugs at the Ukrainian pharmaceutical market are taken by highly affordable drugs, $37.1 \%$ (13 INNs) - drugs with average affordability and only $8.6 \%$ (3 INNs) - drugs with low affordability for the Ukrainian consumers (Fig. 3). But drugs with low affordability are modern and have significant advantages when used in clinical practice compared to available analogs.

CONCLUSIONS

1. The analysis has shown that the range of the first line antihy- pertensive drugs includes 35 INNs of drugs represented by 570 TNs. Most part of the market - 68.5\% is taken by foreign drugs and only $31.1 \%$ - by domestic drugs. The range of antihypertensive drugs includes drugs of different generations: in addition to wellknown drugs there are also new ones that have significant advantages both in terms of clinical efficiency and safety.

2. The analysis of economic affordability of the first line antihypertensive drugs at the maximum price has shown that the vast majority of drugs are highly affordable for the Ukrainian consumers, and their total number when calculated at the maximum price is $54.3 \%$ (19 INNs) of all drugs presented at the Ukrainian pharmaceutical market. The share of drugs with average affordability is $37.1 \%$ (13 INNs); it allows the average citizen of Ukraine taking drugs during the entire treatment of HTN without experiencing a significant impact on his/her own budget, and only $8.6 \%$ (3 INNs) are drugs with low affordability. But drugs with low affordability are modern and have significant advantages when used in clinical practice compared to available analogs.

\section{REFERENCES}

1. Голяченко О.М., Голяченко А.О. // Вісник наукових досліджень (Тернопільська державна медична академія ім. І.Я.Горбачевського). - 2011. - №4. - С. 38-41.

2. Горбась I.М., Смирнова І.П., Кваша О.О., Дорогой А.П. // Артериальная гипертензия. - 2010. - №6 (14). - C. 51-82.

3. Коваленко В.М., Корнацький В.М. Медико-соціальні аспекти хвороб системи кровообігу: Аналітично-статистичний посібник. - К., 2010. - 144 c.

4. Коваленко В.М., Корнацький В.М. Динаміка стану здоров'я народу України та регіональні особливості: Аналітично-статистичний посібник. - К., 2012. - 211 c.

5. Коваленко В.М., Корнацький В.М. Регіональні медико-соціальні проблеми хвороб системи кровообігу: Аналітично-статистичний посібник. - К., 2013. - 239 с.

6. Коваленко Н.В. Керівництво по кардіології. - К.: Морион, 2008. - 460 с.

7. Наказ МОЗ України від 24.05.2012 р. №384 «Про затвердження та впровадження медико-технологічних документів зі стандартизації медичної допомоги при артеріальній гіпертензії».

8. Програмний комплекс «Аптека» компанії «Моріон» [Електронний ресурс] - Режим доступу до caŭmy: http: //pharmbase.com.ua/poisk/.

9. Тиск у нормі - запорука здоров'я // Медичний світ. - 2014. - Електронний ресурс. - Доступ до cmammi: http://medsvit.org/articles/1/396/tisk-u-norm-zaporuka-zdorov-ya/\&print=1

10. Яковлєва Л.В., Бондаренко Д.В. // Укр. біофармац. журн. - 2015. - №2 (37). - С. 4-10. 


\section{АНАЛІЗ ЕКОНОМІЧНОЇ ДОСТУПНОСТІ АНТИГІПЕРТЕНЗИВНОЇ ТЕРАПІЇ ГІПЕРТОНІЧНОЇ ХВОРОБИ Л.В.Яковлєва, О.С.Цвик \\ Національний фармацевтичний університет}

Ключові слова: гіпертонічна хвороба; коефіцієнт доступності; показник адекватності платоспроможності; антигіпертензивні препарати першої лінії застосування

Гіпертонічна хвороба (ГХ) - розповсюджене захворювання, основним проявом якого є підвищення артеріального тиску (АT). На теперішній час ГХ виявлена у 30-40\% дорослого населення країн світу. Поширеність ГХ в популяції з віком збільшується. Серед осіб 18-29 років поширеність ГХ становить 4\%; у віці 50-59 років - 44\%; серед осіб 60-69 років - 54\%, а у віці 70 років і старше - 65\%. Метою даної роботи була оцінка асортименту та економічної доступності антигіпертензивних препаратів. У результаті проведеного аналізу було встановлено, що асортимент антигіпертензивних ЛЗ першої лінії застосування налічує 35 МнН препаратів, які представлені 570 ТН. Більшу частину ринку - 68,5\% складають ЛЗ закордонного виробництва і лише 31,1\% - вітчизняні ЛЗ. Асортимент антигіпертензивних ЛЗ включає препарати різних поколінь: поряд із широко відомими $\epsilon$ нові препарати, що мають суттєві переваги як за клінічною ефективністю, так і за безпечністю. Аналіз економічної доступності показав, що переважна більшість препаратів $є$ високодоступними для українського споживача, їх загальна кількість при розрахунку за максимальною ціною складає 54,3\% (19 МНH) від усіх представлених ЛЗ на фармацевтичному ринку України. Частка середньодоступних препаратів складає 37,1\% (13 МНН), що дає змогу середньостатистичному жителю України приймати ЛЗ протягом усього курсу лікування ГХ, не відчуваючи значного впливу на власний бюджет, і лише 8,6\% (3 МНН) є малодоступними ЛЗ. Але малодоступні ЛЗ $є$ сучасними і мають суттєві переваги при застосуванні в клінічній практиці у порівнянні з доступними аналогами.

\section{ОЦЕНКА ЭКОНОМИЧЕСКОЙ ДОСТУПНОСТИ АНТИГИПЕРТЕНЗИВНОЙ ТЕРАПИИ ГИПЕРТОНИЧЕСКОЙ БОЛЕЗНИ Л.в.Яковлева, О.С.Цвык}

\section{Национальный фармацевтический университет}

Ключевые слова: гипертоническая болезнь; коэффициент доступности; показатель адекватности платежеспособности; антигипертензивные препараты первой линии применения

Гипертоническая болезнь (ГБ) - распространенное заболевание, основными проявлениями которого является повышение артериального давления (АД). В настоящее время ГБ обнаружена у $30-40 \%$ взрослого населения стран мира. Распространенность ГБ в популяции с возрастом увеличивается. Среди лиц 18-29 лет распространенность ГБ составляет 4\%; в возрасте 50-59 лет - 44\%; среди лиц 60-69 лет - 54\%, а в возрасте 70 лет и старше - 65\%. Целью данной работы была оценка стоимости и экономической доступности антигипертензивных препаратов. В результате проведенного анализа было установлено, что ассортимент антигипертензивных ЛС первой линии применения насчитывает 35 МHН препаратов, которые представлены 570 ТН. Большую часть рынка - 68,5\% составляют ЛС зарубежного производства и лишь 31,1\% - отечественные ЛС. Ассортимент антигипертензивных ЛС включает препараты разных поколений: наряду с широко известными представлены новые препараты, имеющие существенные преимущества как по клинической эффективности, так и по безопасности. Анализ экономической доступности показал, что подавляющее большинство препаратов является высокодоступными для украинского потребителя, их общее количество составляет 54,3\% (19 MHН) от всех представленных ЛС на фармацевтическом рынке Украины. Доля среднедоступных ЛС составляет 37,1\% (13 МНH), что позволяет среднестатистическому жителю Украины принимать ЛС в течение всего курса лечения ГБ, не испытывая значительного влияния на собственный бюджет, и лишь 8,6\% (3 МНН) являются малодоступными ЛС. Но малодоступные ЛС являются современными и имеют существенные преимущества при применении в клинической практике по сравнению с доступными аналогами.

Address for correspondence:

Received in 11.04.2016

4, Valentynivska str., Kharkiv, 61168, Ukraine.

Tel. (572) 65-88-95. E-mail: feknfau@ukr.net.

National University of Pharmacy 